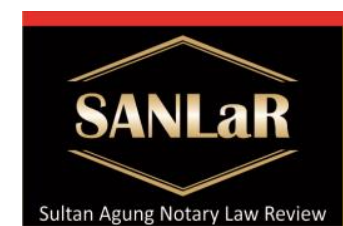

Volume 2 Issue 3, September 2020
Sultan Aqung

Notary Law Review

Credit Agreement and Notary-PPAT...(Muhammad Azka Faizan)
ISSN 2686-4428

published by Faculty of Law semarang

\title{
Credit Agreement and Notary-PPAT Responsibilities for Deed of Mortgage
}

\author{
Muhammad Azka Faizan ${ }^{*}$ and achmad Sulchan ${ }^{* *}$ \\ *) Students of Master of Notary Law, Universitas Islam Sultan Agung (UNISSULA) \\ Semarang, E-mail: azka.faizan666@gmail.com \\ $\left.{ }^{* *}\right)$ Lecturer of Master of Notary Law, Universitas Islam Sultan Agung (UNISSULA) \\ Semarang
}

Abstract. Banks are one financial institution that has an important role in the economy of a country. The problems in this study are (1) What are the factors that hamper the credit agreement and the responsibility of the Notary-PPAT in making the Deed of Granting Mortgage to the BPD Bank of Central Java?, 2) What is the legal consequence if the Notary-PPAT is late in making the Deed of Granting Mortgage to Bank BPD Central Java?, 3) How is the settlement if the Notary-PPAT is late in making the Deed of Granting Mortgage to the Bank BPD Central Java? The method used is the sociological juridical approach, the research specification is analytical descriptive. The results of this study are (1) The cost of increasing SKMHT to APHT because the process of certification of SKMHT objects that have not been registered requires expensive costs. 2) Based on that, SKMHT needs to be regenerated if APHT is to be made. 3) By making a new Power of Attorney Charge (SKMHT), which of course must be with the approval of creditors and debtors.

Keywords: Credit; Agreement; Mortgage.

\section{Introduction}

The Indonesian state is a country based on law (rechtsstaat), not based on mere power (machtsstaat). Indonesia accepts law as an ideology to create order, security, justice and welfare for its citizens. The consequence is that the law binds every action taken by Indonesian citizens, in order to create a just and prosperous Indonesia based on Pancasila and the 1945 Constitution of the Republic of Indonesia, the continuity and enhancement of the implementation of national development based on kinship, needs to be properly maintained..$^{1}$ In order to achieve this goal, the implementation of economic development must pay more attention to the harmony, harmony and sustainability of the elements of equitable development of economic growth and national stability. ${ }^{2}$

\footnotetext{
${ }^{1}$ Arbi, Syarif. (2013). Lembaga: Perbankan, Keuagan dan Pembiayaan, Print. 1, Yogyakarta: BPFE Universitas Gajah Mada. p. 13

${ }^{2}$ Suroto, Pendekatan Institusionil dan Analisis Model Kebijakan Terhadap SK. Direksi Bank Indonesia No. 27/162/Kep/1995, Tentang Pedoman Penyusunan Kebijakan Perkreditan Rakyat (PPKB), Jurnal IImiah, Hukum dan Dinamika Masyarakat, Vol. 22, No, 33 Oktober 2004, April 2004, Accessed 30 January 2020
} 
Notary, in this case is a Notary as PPAT, namely a public official who is given the authority to make authentic deeds regarding certain legal actions regarding land rights or property rights over housing units. Arrange, meanwhile PPAT deed is deed made by PPAT as evidence that certain legal actions regarding land rights or ownership rights over apartment units have been carried out, the PPAT deed is a tool to prove that a legal act has been committed. Therefore, if the legal act is canceled or canceled, the PPAT deed concerned will no longer function as evidence of said legal act. PPAT is appointed and dismissed by the Minister of Agrarian Affairs to serve the community in making PPAT deeds in certain areas. $^{3}$

PPAT working area is a working area of Regency/Municipal Land Office, PPAT which chooses a work area which does not include the location of the office needs to move its office to its working area which newand if he does not vote, then the place where he is assigned has a land office, that is considered his domicile and besides that he is given a grace period of one year to vote, if he does not choose one of these work areas then it is deemed he has chosen the land office in his working area. And is no longer authorized in other work areas after one year of selecting the land office. ${ }^{4}$

PPAT notaries must cooperate (help and complement each other) with the bank to issue a PPAT Notary deed required in a credit agreement that the bank will conclude with its debtor. In this legal research, the researcher refers to the Central Java BPD Bank as the only regional bank that is useful for improving the economy of the community, especially in Central Java which has been a place of savings and credit for the people of Central Java. This Central Java BPD Bank provides credit to the people of Central Java, especially in Pekalongan Regency by using credit guarantees in the form of valuables and securities that can be used as Mortgage Rights. ${ }^{5}$

Policy theory (policy) which is an instrument of government, not only in the sense of government which only concerns the State apparatus, but also governance which touches the management of public resources. In essence, policies are decisions or choices of action that directly regulate the management and distribution of natural, financial and human resources in the public interest. ${ }^{6}$

Based on background above, the problems studied in writing this is What are the factors that hinder the credit agreement and the responsibility of the Notary-PPAT in making the Deed of Granting Mortgage Rights at Bank BPD Central Java, what are the legal consequences if the Notary-PPAT is late in making the Deed of Granting Mortgage Rights at Bank BPD Central Java, and what is the settlement if the Notary-PPAT is late in making the Deed of Granting Mortgage Rights at Bank BPD Central Java.

\footnotetext{
${ }^{3}$ Sutedi, Adrian. (2006). Implikasi Hak Tanggungan Terhadap Pemberian Kredit oleh Bank dan Penyelesaian Kredit Bermasalah. Jakarta: BP. Cipta Jaya. p. 136

${ }^{4}$ A.P. Parlindungan. (1999). Pendaftaran Tanah Indonesia. Bandung: Mandar Maju. p. 177-193

${ }^{5}$ Abdurrahman, Soejono. (1998). Prosedur Pendaftaran Tanah Hak Milik, Hak Sewa Bangunan, Hak Guna Bangunan. Jakarta: Rineka Cipta. p. 26

${ }^{6}$ Suharto, Edi. (2008). Kebijakan Sosial Sebagai Kebijakan Publik. Bandung: CV Alfabeta. p. 13
} 


\section{Research Methods}

The method used in this research is a juridical approach method sociological. This sociological juridical research examines thecredit agreement and the Notary-PPAT's responsibility in drawing up the deed of granting mortgage rights at Bank BPD Central Java. This research is descriptive analytical, with this analytical descriptive research can easily find out the problem (case) associated with other phenomena or symptoms that are related and explain aboutcredit agreement and the Notary-PPAT's responsibility in drawing up the deed of granting mortgage rights at Bank BPD Central Java. And the data collected in this study can be classified into two, namely primary data from field research and secondary data from literature studies.

\section{Results and Discussion}

3.1. Factors Inhibiting Credit Agreements and Notary-PPAT Responsibilities in Making Deed of Granting Mortgage Rights at Bank BPD Central Java

Banks are business entities that carry out activities to collect funds from the public in the form of savings and channel them back to the community in the form of loans or in other forms in an effort to improve people's lives, from the meaning described in Article 1 Paragraph 2 of Act No. 10 of 1998 Concerning Banking, it can be concluded that banking business activities include raising funds, channeling funds, providing other banking services. ${ }^{7}$

In accordance with Article 1 paragraph 11 of Act No. 10 of 1998 concerning Banking, it is stated that credit is an activity of providing invoices or money which is carried out based on an agreement regarding lending and borrowing within a certain period between the creditor or the lending party with another party that requires the borrower or debtor to pay off his debt by giving interest.

Meanwhile, the individual guarantee is a personal guarantee for certain debts from a debtor. $^{8}$

Regarding special matters related to collateral in the form of land, since 1996 there has been a legal unification in the Guarantee Law for land, namely with the issuance of Act No. 4 of 1996 concerning Land Mortgage Rights and Objects related to Land, hereinafter abbreviated as UUHT. The birth of the UUHT is a mandate of Article 51 of Act No. 5 of 1960 concerning Basic Agrarian Principles, which states "Mortgage rights that can be imposed on Property Rights, Business Use Rights, and Building Use Rights in Articles 25, 33 and 39 are regulated by law". ${ }^{9}$

In addition to the rights to land as mentioned above, Article 4 paragraph (2) of the UUHT also regulates that it is also possible that the Right to Use over State Land which

\footnotetext{
${ }^{7}$ Kasmir. (2012). Manajemen Perbankan. Jakarta: Raja Grafindo Persada. p. 13

${ }^{8}$ M. Bahsan. (2007). Hukum Jaminan dan Jaminan Kredit. Jakarta: Raja Grafindo Persada.p. 70

${ }^{9}$ Salim HS. (2005). Perkembangan Hukum Jaminan dilndonesia. Jakarta: Rajawali Pers. p. 96
} 
according to the applicable provisions must be registered and according to its transferable nature can also be encumbered with Mortgage Rights. ${ }^{10}$

As Article 4 paragraph (1) of the UUHT reads, one of the objects of Mortgage Rights is Building Use Rights. It is the right to build and own buildings on land that is not his own, with a maximum period of 30 years. Furthermore, at the request of the right holder and taking into account the needs and condition of the buildings, the 30 year period may be extended for a maximum period of 20 years. Building Use Rights can be transferred and transferred to other parties. Land rights that can be encumbered with a Mortgage Rights according to Article 4 of the UUHT, namely Property Rights, Business Use Rights, Building Use Rights (Articles 25, 33 and 39 of Government Regulation Number 40 of 1996), Use Rights of State Land which according to the applicable provisions must be registered and according to their nature transferable. ${ }^{11}$

Power of Attorney to Charge Mortgage Rights or abbreviated as SKMHT is the power given by the guarantor of the Mortgage as the power of attorney to the special power recipient to charge an object with the Mortgage Rights of SKMHT giver here is the collateral owner, possibly as a debtor at the same time but may not be a debtor but only as the collateral owner. While the SKMHT recipient is confirmed to be a creditor, it cannot be an individual who is not a creditor. ${ }^{12}$

Obstacles in making SKMHT especially by Notary/PPAT which made the SKMHT legally not found. This is because the regulations regarding SKMHT have been clearly regulated in the UUHT, but these obstacles are found in administrative management, namely in the process of using SKMHT to become APHT and the amount of costs required in certifying SKMHT objects that have not been registered. According to information from Handojono Halimana as Notary/PPAT in Central Java. ${ }^{13}$ In the implementation of the SKMHT which has a period of 3 months (Article 15 paragraph (4) UUHT), there is not enough time to arrive at the APHT installation stage, and the consequence is that if the time has passed then the SKMHT will be null and void by law. As a result, the creditor does not have the right to execute the guarantee given by the debtor if it is in default, and the debtor does not get the necessary fees in his business. This can cause losses for both parties.

The roles and responsibilities of PPAT in making APHT legally are the roles and responsibilities in carrying out obligations based on the applicable laws and

\footnotetext{
${ }^{10}$ Patrik, Purwahid \& Kashadi. (2008). Hukum Jaminan. Edisi Revisi dengan UUHT. Semarang: Faculty of Law, University of Diponegoro Semarang. p.87

${ }^{11}$ Harsono, Boedi. (2007). Hukum Agraria Indonesia, Himpunan Peraturan-Peraturan HukumTanah. Jakarta: Djambatan. p. 423

${ }^{12}$ Sutedi, Andrean. (2010). Hukum Hak Tanggungan. Jakarta: Sinar Grafika. p. 60

${ }^{13}$ Interview with Handojono Halimana, as Notary-PPAT City of Pekalongan on January 28, 2020
} 
regulations. ${ }^{14}$ In carrying out his professional duties, a PPAT who receives the deed has obligations before and after making the deed.

His duties include drawing up a credit agreement deed requested by the bank, providing guidance to the bank regarding credit ${ }^{15}$ documents, making final credit documents, confirming the data to the bank if there are things that are unclear or unclear, keeping the name of the debtor and the amount confidential credit requested, and enter it in the register book in order to be registered with the district court. In the implementation in the field, the imposition of Mortgage Rights, there are two differences, namely the imposition of which APHT can be made directly where the certificate is already in the name of the debtor/guarantor of his own Mortgage Rights and the imposition of Mortgage Rights which cannot be directly made APHT in other words must be preceded by SKMHT provide guidance to banks with regard to credit documents, make final credit documents, confirm this data to the bank if there are things that are unclear or unclear, keep the name of the debtor and the amount of credit requested, and enter it in the register book to be registered with District Court. In the implementation in the field, the imposition of Mortgage Rights, there are two differences, namely the imposition of which APHT can be made directly where the certificate is already in the name of the debtor/guarantor of his own Mortgage Rights and the imposition of Mortgage Rights that cannot be directly made APHT in other words must be preceded by SKMHT provide guidance to banks with regard to credit documents, make final credit documents, confirm this data to the bank if there are things that are unclear or unclear, keep the name of the debtor and the amount of credit requested, and enter it in the register book to be registered with District Court. In the implementation in the field, the imposition of Mortgage Rights, there are two differences, namely the imposition of which APHT can be directly made where the certificate is already in the name of the debtor/guarantor of his own Mortgage Rights and the imposition of Mortgage Rights which cannot be directly made APHT in other words must be preceded by SKMHT. Keep the name of the debtor and the amount of credit requested confidential, and enter it in the register in order to be registered with the district court. In the implementation in the field, the imposition of Mortgage Rights, there are two differences, namely the imposition of which APHT can be directly made where the certificate is already in the name of the debtor/guarantor of his own Mortgage Rights and the imposition of Mortgage Rights which cannot be directly made APHT in other words must be preceded by SKMHT. Keep the name of the debtor and the amount of credit requested confidential, and enter it in the register in order to be registered with the district court. In the implementation in the field, the imposition of Mortgage Rights, there are two differences, namely the imposition of which APHT can be directly made where the certificate is already in the name of the debtor/guarantor

\footnotetext{
${ }^{14}$ Adjie, Habib. (2008). Hukum Notaris Indonesia, Tafsir Tematik Terhadap UndangUndang Nomor 30 Tahun 2004 Tentang Jabatan Notaris. Bandung: RefikaAditama. p. 6

${ }^{15}$ Chusna, Amalia., \& Hafidz, Jawade. (2019). The Role of the Notary in the Credit Agreement with Mortgage Guarantee (Case Study in the Bank Tabungan Negara (Persero) Tbk). JURNAL AKTA: Vol. 6, No. 4, 719-726. Retrieved from http://jurnal.unissula.ac.id/index.php/akta/article/view/7668
} 
of his own Mortgage Rights and the imposition of Mortgage Rights which cannot be directly made APHT in other words must be preceded by SKMHT. ${ }^{16}$

\subsection{The legal consequence is if the Notary-PPAT is late in making the Deed of Granting Mortgage Rights at Bank BPD Central Java}

The granting of power or lastgeving in Dutch is an agreement whereby a person gives power or power (macht) to another person, who receives it for and on behalf of the authorizer (lastgever). The method of granting and receiving power of attorney can be done by authentic deed, by handwriting, by ordinary letter and or orally. ${ }^{17}$ As for the acceptance apart from explicitly, it can also be tacitly and the implementation can be concluded. It is not promised that the granting of power is free. Based on Article 1795 of the Civil Code explains that: "The granting of power can be done specifically, namely regarding only one or more specific interests, or in general, namely covering all the interests of the grantor. On special powers, only contains certain tasks. The power of attorney only instructs the recipient of the power of attorney to carry out certain things or things, for example the power to sell a house or the power to sue a certain person according to the provisions of Article 1795 of the Civil Code.

This power of attorney is done by making SKMHT. SKMHT is a special power of attorney addressed to the Mortgage holder or other party to represent the Mortgage giver in the presence of the Notary/PPAT to charge the Mortgage Rights, since the Mortgage Giver does not come to face alone to take action to charge the Mortgage before a Notary or PPAT. The use of SKMHT is often used to delay the imposition of Mortgage Rights for credit guarantees. Many creditors who hold SKMHT will only be implemented if there are symptoms that the debtor will default. Even though the risk due to the Mortgage Rights has not been charged, it is fully borne by the creditor (guarantee holder).

The SKMHT giver here is the collateral owner, while the SKMHT recipient is the guarantee recipient. The making of SKMHT is dilated due to various interests and obstacles, especially because the process of assigning, granting and installing Mortgage Rights is not easy, among others, due to the following things, having to go through a certain formality, taking a long time, requiring relatively high cost of loading, The loan term provided by creditors to debtors is basically too short and the amount is not too large. ${ }^{18}$

Conversely, the debtor also feels helped and safe by the placement of Mortgage Rights by the creditor. SKMHT was made due to time problems, for example, because a bank director was the party who needed to sign, and at the time of making APHT, he

\footnotetext{
${ }^{16}$ Interview with Agung Prasetyo, as the Debtor of the BPD Central Java Pekalongan Branch on January 29, 2020

${ }^{17}$ Andarsasmita, Komar. (1990). Contoh Akta Otentik Dan Penjelasan (Notaris II). West Java: West Java Regional Indonesian Notary Association. p. 453

${ }^{18}$ Supriadi. (2012). Hukum Agraria. Bandung: Sinar Grafika. p. 186.
} 
represented the parties, so that the time problem here is because the bank held two positions at the time of making APHT, namely the position as a party the bank as the creditor, and also the position as a debtor, ${ }^{19}$ because the bank, which is represented by a director, must carry out two positions, and knowing that the position as a director of a bank has great duties and authority, he cannot just leave his responsibilities, so an SKMHT is necessary from the bank. Preparation of this SKMHT must be done with a notary deed or PPAT deed as regulated in the provisions of Article 15 paragraph (1) of the UUHT. Based on the provisions of the article, the authorities to make an SKMHT are Notary and PPAT which is done by making a notary deed or with a PPAT deed. For the validity of an SKMHT, apart from having to be made with a notary deed or PPAT deed.

Based on this, the legislators set a time limit for SKMHT in which in general the validity period of an SKMHT is regulated in Article 15 paragraph (3) and paragraph (4) UUHT, namely: a. For SKMHT regarding registered land rights, it must be followed by making APHT at the latest 1 (one) month after the SKMHT is signed. b. For SKMHT regarding land rights that have not been registered, it must be followed by making APHT no later than 3 (three) months after the SKMHT is signed.

\subsection{Settlement if the Notary-PPAT is Late in Making a Deed of Granting Mortgage Rights at Bank BPD Central Java}

There is an obligation to make SKMHT and APHT with a notarial deed followed by registration, then this obligation will definitely require additional costs to burden the debtor, who in this case are generally small entrepreneurs with a very small guarantee value as well, with the imposition of additional fees. This makes the debtor object, because the debtor incurs a large amount of money, while the debtor only gets a small credit facility. The imposition of mortgage rights as stated in the Law on Insurance Rights must be attended by the guarantor of the mortgage right before a Notary or PPAT. $^{20}$

If the guarantor of the mortgage right cannot appear before the Notary or PPAT, then he can give the power to represent him before the Notary or PPAT. Such power of attorney must be in the form of an authentic power of attorney drawn up before an authorized official, be it a Notary Public or PPAT. There are SKMHT provisions that recognize time limits and there are those that do not recognize time limits, for SKMHT which regarding the time limit must be immediately made to implement the imposition of Mortgage Rights because it is limited by the period of time, which for the period of time has been regulated in the Law of Mortgage Rights (UUHT) Number 4 of 1996 Article 15 paragraph (3) and paragraph (4). SKMHT regarding registered land rights must be followed by making APHT no later than 1 (one) month after it is granted.

\footnotetext{
${ }^{19}$ Usman, Rachma. (2013). Hukum Kebendaan. Jakarta: Sinar Grafika. p. 437.

${ }^{20}$ J. Satrio. (1998). Hukum Jaminan, Hak Jaminan Kebendaan, Hak Tanggungan. Bandung: Citra Aditya Bakti. p. 21
} 


\section{Closing}

The legal consequence is if the Notary-PPAT is late in making the Deed of Granting Right of Dependent on Bank BPD Central Java is null and void. Based on this, SKMHT needs to be regenerated if an APHT is to be made. As a result of the legality of the SKMHT, the SKMHT cannot be used as the basis for making APHT. Thus, the general guarantee provisions contained in the provisions of Article 1131 of the Civil Code will apply and creditors as concurrent creditors as mandated in the provisions of Article 1132 of the Civil Code which stipulate: "The material becomes joint collateral for all those who deposit on it, the income from the sale of goods.

\section{References}

Journal:

[1] Chusna, Amalia., \& Hafidz, Jawade. (2019). The Role of the Notary in the Credit Agreement with Mortgage Guarantee (Case Study in the Bank Tabungan Negara (Persero) Tbk). JURNAL AKTA: Vol. 6, No. 4, 719-726. Retrieved from http://jurnal.unissula.ac.id/index.php/akta/article/view/7668

[2] Suroto, Pendekatan Institusionil dan Analisis Model Kebijakan Terhadap SK. Direksi Bank Indonesia No. 27/162/Kep/1995, Tentang Pedoman Penyusunan Kebijakan Perkreditan Rakyat (PPKB), Jurnal IImiah, Hukum dan Dinamika Masyarakat, Vol. 22, No, 33 Oktober 2004, April 2004, Accessed 30 January 2020

Books:

[1] A.P. Parlindungan. (1999). Pendaftaran Tanah Indonesia. Bandung: Mandar Maju

[2] Abdurrahman, Soejono. (1998). Prosedur Pendaftaran Tanah Hak Milik, Hak Sewa Bangunan, Hak Guna Bangunan. Jakarta: Rineka Cipta

[3] Adjie, Habib. (2008). Hukum Notaris Indonesia, Tafsir Tematik Terhadap UndangUndang Nomor 30 Tahun 2004 Tentang Jabatan Notaris. Bandung: RefikaAditama

[4] Andarsasmita, Komar. (1990). Contoh Akta Otentik Dan Penjelasan (Notaris II). West Java: West Java Regional Indonesian Notary Association

[5] Arbi, Syarif. (2013). Lembaga: Perbankan, Keuagan dan Pembiayaan, Print. 1, Yogyakarta: BPFE Universitas Gajah Mada

[6] Harsono, Boedi. (2007). Hukum Agraria Indonesia, Himpunan Peraturan-Peraturan Hukum Tanah. Jakarta: Djambatan

[7] J. Satrio. (1998). Hukum Jaminan, Hak Jaminan Kebendaan, Hak Tanggungan. Bandung: Citra Aditya Bakti

[8] Kasmir. (2012). Manajemen Perbankan. Jakarta: Raja Grafindo Persada

[9] M. Bahsan. (2007). Hukum Jaminan dan Jaminan Kredit. Jakarta: Raja Grafindo Persada 
[10] Patrik, Purwahid \& Kashadi. (2008). Hukum Jaminan. Edisi Revisi dengan UUHT. Semarang: Faculty of Law, University of Diponegoro Semarang

[11] Salim HS. (2005). Perkembangan Hukum Jaminan dilndonesia. Jakarta: Rajawali Pers

[12] Suharto, Edi. (2008). Kebijakan Sosial Sebagai Kebijakan Publik. Bandung: CV Alfabeta

[13] Supriadi. (2012). Hukum Agraria. Bandung: Sinar Grafika

[14] Sutedi, Adrian. (2006). Implikasi Hak Tanggungan Terhadap Pemberian Kredit oleh Bank dan Penyelesaian Kredit Bermasalah. Jakarta: BP. Cipta Jaya

[15] Sutedi, Andrean. (2010). Hukum Hak Tanggungan. Jakarta: Sinar Grafika

[16] Usman, Rachma. (2013). Hukum Kebendaan. Jakarta: Sinar Grafika

\section{Regulations:}

[1] Constitution Republic of Indonesia 1945

[2] Act No. 10 of 1998 on Banking

[3] Act No. 4 of 1996 concerning Mortgage Rights to Land and Objects Related to Land

[4] Act No. 5 of 1960 concerning Basic Agrarian Regulations

Interview:

[1] Interview with Agung Prasetyo, as the Debtor of the BPD Central Java Pekalongan Branch on January 29, 2020

[2] Interview with Handojono Halimana, as Notary-PPAT City of Pekalongan on January 28,2020 